\title{
INTERDISCIPLINARY ASPECTS OF TEACHING ENGLISH FOR SPECIFIC PURPOSES VIA BILINGUAL PROJECTS
}

\author{
Veronia MARTYNYUK \\ Kyiv National University of Trade and Economics, Ukraine \\ Olena KRAVCHENKO \\ Yuriy Fedkovych National University, Chernivtsi, Ukraine
}

\begin{abstract}
The present paper deals with innovative approaches to teaching English for Specific Purposes (ESP) in the field of interdisciplinarity. The paper starts with the novelty and topicality of the issue in question. It makes an attempt to eliminate a contradiction now apparent in Ukrainian education regarding the theoretical foundations and practical application of the basic ESP principles in vocational schools and universities. The authors explore the concept of interdisciplinarity and its didactic potential when applied to the ESP teaching process. It is stated that the interdisciplinary approach is able to provide new and exciting possibilities when it stimulates the learners' interest in foreign languages both in and outside of an educational environment. The paper introduces a new methodological option in the ESP educational process - an interdisciplinary bilingual project. As it dares to be an innovative type of group project, some theoretical considerations are necessarily discussed. Its basic categories, implementation objectives, interdisciplinary characteristics are identified. The paper justifies the didactic appropriateness of the project in question and its interdisciplinary practicality.
\end{abstract}

Keywords: interdisciplinarity, bilingual project, group project, English for Specific Purposes, professional/ vocational training, educational environment

\section{Topicality}

To train EFL students to be effective foreign language learners and fluent foreign language speakers in a multilingual professional setting is a great 
challenge for contemporary education on the whole and any particular type of educational institution (be it a university or a vocational school). The Ukrainian educational management in its secondary and tertiary stages is facing the task of tackling the issue of multilingualism as an essential element of the current students' professional needs at micro -, meso - and macro-levels. The problem is viewed as a vital issue especially for those educational establishments that are located in the areas bordering on the EU countries. The focus of our attention is Chernivtsi Oblast' which lies is the southwestern part of Ukraine and shares a border with the Republic of Moldova and Romania. Historically, a considerable part of the population of this area has been bilingual and/ or fluent in several languages such as Ukrainian, Romanian, German, Russian, Yiddish, and Polish. In recent years, intensive cross-border cooperation and communication with the EU countries has sharply increased a demand for foreign language fluency, especially English, Romanian, Italian, German and Polish, which in its turn inevitably asks for an intensification of bi/multi-language professional training and cultural literacy.

Furthermore, EFL/ ESP teachers from both Chernivtsi universities and vocational schools have to deal with a complex ethical dilemma: what should be the focus of their personal teaching practice - EFL in its 'pure form' that trains four language skills, - or interdisciplinary self-development in the target professional/ vocational field accompanied by a recurring needs analysis to determine which language skills are most needed by their students? The authors of this article, who are EFL/ESP university and vocational school teachers, make an attempt to eliminate a contradiction that is manifest in Ukrainian education regarding the theoretical foundations and practical application of the basic ESP principles in the current Ukrainian secondary and tertiary education, where teaching practices are still conventional and conservative in nature and fail to respond to the demands of the ever-changing European labour market.

The novelty of the problem in question is obvious: on the one hand, the present paper explores the concept of interdisciplinarity and its didactic potential when applied to the ESP teaching process in Ukraine. On the other hand, the authors introduce an innovative approach to ESP teaching via bilingual projects and give didactic instructions on successful project implementation. Therefore, we put forward the following aims and objectives: a) to explore the concept of interdisciplinarity and its didactic potential when applied to the ESP teaching process; b) to introduce, champion and promote the interdisciplinary bilingual project (IBP) for ESP teaching/learning; c) to identify the IBP basic categories, implementation objectives, and interdisciplinary characteristics; d) to justify the didactic appropriateness of the project in question and its interdisciplinary applicability. 


\section{Theoretical Background}

To send the research the right way, it is necessary to explore the concept of interdisciplinarity when applied to the ESP teaching process. Numerous definitions of interdisciplinarity $[5 ; 6 ; 8]$ demonstrate unanimity of thought, i.e.

The term interdisciplinary is applied within education and training pedagogies to describe studies that use methods and insights of several established disciplines or traditional fields of study. Interdisciplinarity involves researchers, students, and teachers in the goals of connecting and integrating several academic schools of thought, professions, or technologies - along with their specific perspectives - in the pursuit of a common task. (qtd. in Jacobs, 43-65)

Ukrainian scholars (Oliynyk V., Martynyuk V., Zabolotna O., et alii) view interdisciplinarity in its broad and narrow senses: a) as an approach that deals with a subject which goes out of its disciplinary field with its aim being kept within the framework of a target disciplinary study but its methods being transferred from one discipline into others; b) as an approach that integrates methods from different disciplines by either modifying them or creating a new method of study which goes beyond a particular disciplinary field. In other words, an interdisciplinary approach is a cooperation of different scientific branches in the process of a particular discipline study that can vary from simply sharing ideas to mutually integrating different concepts and methodologies. Interdisciplinarity in education is viewed through correlation of subjects, through themes, topics or ideas, practical thinking, and also through the learner's keen interest in independent inquiry-based learning.

Let us consider a model of interdisciplinarity, suggested by Alexander Jensenius (Jensenius, 2017).

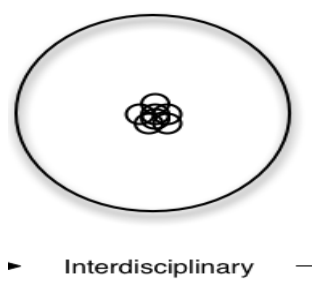

Figure 1. Model of interdisciplinarity (by Alexander Jensenius)

The model demonstrates that an interdisciplinary analysis requires an integration of knowledge on a given issue from different subjects. Disciplinary knowledge, concepts, tools, and rules of investigation are considered, contrasted, and combined in such a way that the resulting awareness is greater than simply the 
sum of its disciplinary parts (Seipel, 2017). As we see, interdisciplinarity deals with a scientific approach which tends to leave the framework of its disciplinary field because its objective is not only to transfer methods but also to integrate separate and distinct disciplines into a new educational entity. Interdisciplinarity does not follow a disciplinary curriculum or discipline-based educational process, nor does it admit the virtue of gaining knowledge on a discrete subject, because its target is a holistic thinking ability.

In our didactic investigations we give preference to a model of interdisciplinarity based on the ideas of Basarab Nicolescu (Nicolescu, 2007), a Romanian theoretical physicist. According to Nicolescu, interdisciplinarity concerns collaborations between contrasting academic disciplines or research methods for new applications, new analyses, or the creation of entirely new disciplines. Picture 2 demonstrates a new type of interdisciplinary 'spatial imagination' in the sphere of educational collaboration processes.



Figure 2. Model of interdisciplinarity (after Basarab Nicolescu)

This model shows that the interdisciplinary approach in education can be of several different types: a) fragmentary, when interdisciplinary tiers activate only separate/isolated parts of the whole content; b) nodal, when interdisciplinary tiers are used within the framework of a separate lesson to gain advanced knowledge of a given topic; c) integrated, when different disciplines are consequentially interpenetrating to create a holistic vision and understanding of a problem.

The present paper discusses interdisciplinary aspects in ESP teaching in higher education and vocational schooling a) when implemented fragmentarily and b) in an integrated collaboration. Here we should take into consideration that ESP teaching in Ukraine is divided into two main areas: English for Academic Purposes (EAP) and English for Professional Purposes (EPP) or EOP (English for Occupational Purposes). In our case, EAP is related to a wide range of courses delivered to university undergraduates who study for the Bachelor of 
English Language. EPP (EOP) is taught to students of vocational schools who receive specialized training and apprenticeship that leads to qualifications (diplomas and certificates) in a variety of occupations, handicraft and trades. We can assume that the interdisciplinary approach, when applied to ESP (EAP/EPP), has a lot of potential to provide new and exciting possibilities to stimulate the learners' interest in foreign languages and encourage them to make linguistic inquiry both in and outside a specific educational environment of academic and vocational training.

\section{Interdisciplinary Bilingual Project Methodology}

The present paper introduces a new approach to ESP teaching, namely the interdisciplinary bilingual project (IBP). Since it is a novel methodological option in the existing group project classification, it is, therefore, important to elaborate on several essential points of this new methodological approach. We define the interdisciplinary bilingual project (IBP) as a planned interdisciplinary collaboration that is performed over a fixed period of time and is intended to achieve a particular professional/vocational purpose in an artificially created bilingual educational environment. A particular IBP may have a twofold professional/vocational purpose: to produce a tangible (material, substantial, physical) and an intangible (non-material, mental, spiritual) product. The former, in our case, is freshly-baked scones, i.e. physical objects. The latter is a new learning experience for the participating students, a deeper understanding of the subject matter, improved EFL/ESP and professional/vocational skills, an enhanced interest in acquiring working knowledge of English, and culture literacy.

The IBP involves practicing academic/vocational content in two languages (native and foreign) with varying amounts of each language used in accordance with the IBP procedural collaboration. We distinguish different types of possible bilingual collaboration in the framework of the IBP: pure, mixed, consistent, natural and artificial. To develop a motivating artificial bilingual setting for EFL students it is necessary to adhere to the following principles: a) intensive intrinsic and extrinsic motivation of the participating students and teachers of different subjects; b) a reasonable level of language proficiency (vocational school students - pre-intermediate, intermediate or A2, B1; university undergraduates - upper-intermediate, advanced or B2, C1); c) regular ESP training; d) lack of a permanent foreign language environment. Since a great number of students from Chernivtsi universities and vocational schools actively participate in international projects, trainings, seminars, conferences and professional competitions organized abroad, they need a proper level of communicative competence in ESP. Besides, a lot of Chernivtsi students look for summer jobs in Europe where they are expected to speak a foreign language. 
To meet the demands of the labour market, ESP teachers try to create for their students a bilingual professional environment in the framework of their establishments' curricula.

The pilot project in this area was successfully launched by EFL/EAP teachers of the Department of English (Chernivtsi Yuriy Fedkovych National University) and EFL/EPP teachers of the Culinary Unit (Chernivtsi High School of Commerce affiliated with the Kyiv National Trade and Economics University). The project was headlined 'English as an Instrument of Personal and Professional Development'. It was an educational project with salient interdisciplinary bilingual characteristics. The IBP aimed at giving university and vocational school students: a) clear advantages in terms of foreign language, cultural, social, cognitive and personal development, without any loss in the mainstream subjects learning; b) awareness of the link between ESP language studies and personal employment needs.

The pilot IBP workshop included the University's Year 2 undegraduates and the vocational school's Culinary Unit students, EFL/ESP teachers, vocational subject teachers, and American Peace Corps volunteers. A number of visitors attended the workshop, among them the vocational school's administrators, local restauranteurs (prospective employers) and mass media representatives. The Principle of the High school and Chernivtsi National University's Head of English enthusiastically supported the IBP and closely supervised its preparation and procedure; they were highly content with the students' progress and growing interest in the suggested topics and skills trained. So the authors did not encounter any obstacles in setting up this didactic experiment and selecting groups of students for the IBP post-pilot workshops.

Initially, the ESP teachers outlined a conceptual framework for the IBP and one for its organizational management, which contained several gradual, unfolding didactic stages:

1. presentation of the IBP idea;

2. dispute resolution;

3. identification of needs and specification of goals;

4. SWOT analyses;

5. lesson planning;

6. prognosis of teaching/learning outcomes.

The authors agree that a substantial obstacle to interdisciplinarity in the educational environment is a psychological rather than an organizational one because the IBP's success largely depends on collaboration between teachers, who are people of different temperaments and dispositions, educational and research backgrounds, personal goals and ambitions. Effective interdisciplinary teaching and learning happens when specialists in different disciplinary fields act together to serve a common educational purpose and provide guidance and advice to enthuse their students by making them see connections between 
different subject areas in their courses of study. The IBP team its has to first specify and correlate the following key issues: to select and agree upon the areas of collaboration; to determine the interdisciplinary tiers of the university and vocational school EFL/ESP curricula; to select relevant thematic vocabulary to be revised, activated and expanded; to determine the levels of professional/vocational competence needed; to agree on locations, dates and times for the project. Practice proved that didactic logistics was critical to the success of this project. Besides, one should take into consideration some specific factors that may have a considerable bearing on the productivity of the collaboration - material and technical possibilities of the institutions in question; professional qualification of the ESP and vocational subject teachers, their competence in innovative teaching technologies.

To select a topic for this collaborative venture, the IBP team relied upon B.C. Choi's ideas of interdisciplinarity in education (Choi, 2006). He states that on the basis of epistemological proximity, disciplines often cluster into groups (or knowledge subsystems). The more disparate the disciplines, the more different the perspectives are. This leads to a greater chance of success in tackling a complex problem. In our case (Table 1) the content of each target discipline was divided into three arbitrary "levels" of relevant disciplinary literacy and foreign language (FL) competence, (e.g. first, second and third), representing a movement from the core concepts of the discipline to holistic knowledge. When applied to the IBP the levels of different disciplines were perceived to be interpenetrating, that is the third level of a particular discipline/subject could penetrate the first or the second level of the discipline in the next tier and so on.

\begin{tabular}{|c|c|c|c|}
\hline $\begin{array}{l}\text { University } \\
\text { disciplines } \\
\text { (Department of } \\
\text { English) }\end{array}$ & First level & Second level & Third level \\
\hline $\begin{array}{l}\text { EFL } \\
\text { (Conversation } \\
\text { and Discussion) } \\
\text { (foreign } \\
\text { language) }\end{array}$ & $\begin{array}{l}\text { core thematic } \\
\text { vocabulary: words and } \\
\text { word combinations; } \\
\text { basic language and } \\
\text { grammar structures }\end{array}$ & $\begin{array}{l}\text { oral statements } \\
\text { (phrases/remarks/ } \\
\text { utterances); } \\
\text { complex syntactic } \\
\text { units; } \\
\text { micro-texts }\end{array}$ & $\begin{array}{l}\text { effective } \\
\text { communication on } \\
\text { various topics; } \\
\text { fluency of speech } \\
\text { act production; } \\
\text { skilled discourse } \\
\text { strategies } \\
\text { (monologue, } \\
\text { dialogue) }\end{array}$ \\
\hline $\begin{array}{l}\text { Methodology of } \\
\text { TEFL } \\
\text { (foreign }\end{array}$ & $\begin{array}{ll}\text { basic } & \text { TEFL } \\
\text { terminology } & \end{array}$ & $\begin{array}{l}\text { TEFL educational } \\
\text { conversation }\end{array}$ & $\begin{array}{l}\text { effective } \\
\text { professional } \\
\text { communication; }\end{array}$ \\
\hline
\end{tabular}


3. Linguaculture 1, 2020

\begin{tabular}{|c|c|c|c|}
\hline language) & & & $\begin{array}{l}\text { skilled } \quad \text { TEFL } \\
\text { discourse strategies }\end{array}$ \\
\hline $\begin{array}{l}\text { ESP } \\
\text { (foreign } \\
\text { language) }\end{array}$ & $\begin{array}{ll}\text { academic terminology: } \\
\text { words and } & \text { word } \\
\text { combinations; } & \text { basic } \\
\text { structures } & \end{array}$ & $\begin{array}{l}\text { oral statements } \\
\text { (phrases/remarks/ } \\
\text { utterances); } \\
\text { complex syntactic } \\
\text { units; } \\
\text { micro-texts }\end{array}$ & $\begin{array}{l}\text { fluent } \\
\text { communication in a } \\
\text { variety of specific } \\
\text { topics } \\
(e . g . \quad \text { cooking, } \\
\text { English/American/ } \\
\text { Ukrainian cuisine; } \\
\text { baking, restaurant } \\
\text { service, etc.) }\end{array}$ \\
\hline \multicolumn{4}{|l|}{$\begin{array}{l}\text { Vocational } \\
\text { School subjects } \\
\text { (Culinary Unit) } \\
\end{array}$} \\
\hline $\begin{array}{l}\text { EPP (EOP) for } \\
\text { cooks, bakers, } \\
\text { waiters and } \\
\text { bartenders } \\
\text { (foreign } \\
\text { language) }\end{array}$ & $\begin{array}{l}\text { professional } \\
\text { terminology } \\
\text { (e.g. pastry \& baking; } \\
\text { kitchen and restaurant } \\
\text { vocabulary, etc.) }\end{array}$ & $\begin{array}{l}\text { oral statements: } \\
\text { thematic words, } \\
\text { word } \\
\text { combinations, } \\
\text { phrases, remarks, } \\
\text { utterances }\end{array}$ & $\begin{array}{l}\text { complex syntactic } \\
\text { units, micro-texts } \\
\text { (e.g. cooking/baking } \\
\text { instructions, etc.) }\end{array}$ \\
\hline $\begin{array}{l}\text { Technology of } \\
\text { Baking and } \\
\text { Pastry } \\
\text { Manufacturing } \\
\text { (nativel first } \\
\text { language) }\end{array}$ & $\begin{array}{l}\text { technological } \\
\text { terminology } \\
\text { (e.g. cooking, baking, } \\
\text { pastry manufacturing } \\
\text { process, etc.) }\end{array}$ & $\begin{array}{l}\text { Techniques, } \\
\text { instructions, } \\
\text { recipes, } \\
\text { ingredients, etc., } \\
\text { and occupational } \\
\text { discourse (e.g. } \\
\text { cooking and } \\
\text { baking, etc.) }\end{array}$ & $\begin{array}{l}\text { productive } \\
\text { (advanced) } \\
\text { interpersonal } \\
\text { communication } \\
\text { skills; advanced } \\
\text { vocational skills in } \\
\text { pastry } \\
\text { manufacturing and } \\
\text { baking, presentation } \\
\text { skills }\end{array}$ \\
\hline $\begin{array}{l}\text { Baking \& Pastry } \\
\text { Craft } \\
\text { (native / first } \\
\text { language) }\end{array}$ & $\begin{array}{l}\text { kinds of bread and } \\
\text { pastry, intricacies of } \\
\text { the craft, } \\
\text { pastry crafting, } \\
\text { Ukrainian and English } \\
\text { specialties; baking } \\
\text { proper- producing a } \\
\text { tangible product ; } \\
\text { (e.g. English scones) }\end{array}$ & $\begin{array}{llr}\text { basic } & \text { skills } & \text { in } \\
\text { pastry } & \text { craft } & \text { and } \\
\text { design } & & \end{array}$ & $\begin{array}{l}\text { advanced skills in } \\
\text { pastry craft and } \\
\text { design, presentation } \\
\text { skills } \\
\text { (e.g. pastry design } \\
\text { presentation) }\end{array}$ \\
\hline $\begin{array}{l}\text { Restaurant } \\
\text { Service } \\
\text { (native/first } \\
\text { language) }\end{array}$ & $\begin{array}{l}\text { core } \\
\text { thematic/occupational } \\
\text { language (e.g. taking } \\
\text { orders, } \quad \text { giving } \\
\text { instructions; talking } \\
\text { about menu items and }\end{array}$ & $\begin{array}{l}\text { basic training in } \\
\text { restaurant and } \\
\text { food service skills }\end{array}$ & $\begin{array}{lr}\text { advanced } & \text { food } \\
\text { server } & \text { skills } \\
\text { demonstration } & \end{array}$ \\
\hline
\end{tabular}


specialties, etc.)

Table 1. Hierarchy of levels in target IBP disciplines

The table grids (Table I) demonstrate subsystems that correlate within the IBP thus giving way to a new experience, a new practice and interdisciplinary thinking. Here, the interpenetrating tiers are: a) TEFL and EPP (EOP) skills in the professional environment of baking and pastry manufacturing and restaurant service; b) TEFL and EPP (EOP) skills demonstration; c) fluent EFL/ESP communication; d) presentation of the tangible product and serving skills demonstration. No doubt, professional terminology and skills lie at the core of each subject/discipline field; they are not purely theoretical concepts or goals in themselves, but make a solid foundation of interdisciplinarity in a professional setting. Therefore, knowledge acquired in the IBP is first correlated, then shared and finally blended, losing its disciplinary distinctions. Practice proves that the IBP fits the edge between multidisciplinarity and interdisciplinarity.

The IBP procedure reflected the ideas of interdisciplinary didactics and provided ample opportunity to encourage more active use of English in a professional setting that simulated real-life manufacturing processes and academic realities. The Culinary Unit students were set a task to make scones, a popular English kind of round cake served at teatime, in the English language environment that was artificially created by the university undergraduates and ESP/EFL teachers who were assisted by American Peace Corps volunteers and food technology counselors. The undergraduates were set a task to act as FL instructors in the professional setting of Culinary Arts, thus testing and developing their academic knowledge, their skills in TEFL and communicative competencies. The students' collaborative work was observed by a group of ESP and vocational subject teachers, food technologists and culinary experts who were guiding the students' collaborative interaction; they were allowed to give occasional professional advice.

At the outset of the project 'the bakers' tended to fall back upon their mother (first) tongue (s) - Ukrainian or Romanian, but gradually they got into stride and started using English tentatively, first, in mostly single-word utterances or short flashes of conversation, but gradually they grew more confident and started speaking English in a more active and appropriate way. Occasionally, the students lapsed into their first tongue (s), but then they were "punished" by the teachers who would put salt into their dough. It was funny and challenging but no scone was over-salted! The fear of 'penalty' introduced some humour into the workshop and created a friendly an exhilarating atmosphere. The IBP ended with a tangible product (e.g. freshly baked scones) presentation made in English by 'the bakers' who were doing their best to follow the guidelines given by their university peers regarding the content of the presentation and its structure. Then, the culinary students demonstrated their 
skills in the afternoon tea (cream tea) table setting; they gave instructions to each other and commented on what they were doing in English; the undergraduates concluded the presentation with some remarks on English tea drinking traditions, afternoon and cream tea etiquette, as well as some other relevant cultural issues. And finally, all participating students, together with the team of teachers and visitors, partook of the scones.

In follow-up lessons, the IBP participants were required to do a questionnaire. The students' answers showed that both groups enjoyed the IBP. Everybody was highly motivated and eager to engage in other activities along these lines. The students remarked on their partners' (peers) and instructors friendly manner, adequate skills, consideration and desire to create a positive rapport. The IBP participants were able to assess their own level of proficiency /competence in their fields (cooking and baking/restaurant service/ English Language/ TEFL/ as well as their communication skills.

When reviewing the IBP's outcomes, all the students were supposed to give feedback on the IBP and discuss their observations, feelings and skills. The students improved their knowledge of English, the compulsory vocational subjects and know-how in other relevant fields. The overriding emotion was that such projects were of utmost importance for prospective EFL teachers and restaurant cooks, bakers and waiters. The culinary students were unanimous in starting to view the English language fluency as an asset.

An important factor in the success of this project was the way it was set up, managed and monitored. Moreover, it had a strong impact on the vocational subject teachers and cooking instructors who appreciated the EFL/ESP teachers' creative effort and virtues of interdisciplinary teaching. They found the IBP ideas thought-provoking. Furthermore, the session of ESL teachers' reflection encouraged the cooking instructors to consider adopting some of the key activities and issues that were meant to be interpenetrating between tiers. It was a great opportunity to re-evaluate the teachers' prior experience and become aware of the new interdisciplinary knowledge.

A conclusion was drawn that the IBP was a valuable experience for those who plan to take further bilingual interdisciplinary training courses and/or a higher education course (in this country or abroad), to do well in teaching practice and to pursue a successful career in their profession or occupation in the future.

\section{Conclusion}

The IBP achieved the desired didactic goals and demonstrated: a) a positive effect on the development of the students' language skills, as well as their active use of English in the ESP environment; b) a direct impact on the ESP teaching style and learning styles. Furthermore, the IBP experience and post-project 
reviews, reflections and activities (e.g. students' vocabulary test scores) revealed highly commendable results in improved EFL skills, and a good overall attitude to and performance in other subjects.

The IBP practical experience proves that it is possible to balance declarative and procedural knowledge in order to develop new interdisciplinary structural skills and abilities. A novel mode of interaction between teaching and learning, the IBP successfully integrates various disciplines into a new educational entity that comprises several interpenetrating interdisciplinary tiers. The IBP avoids strict disciplinarity. Participating in the IBP makes students understand meaningful connections that exist among the disciplines and unite them into a new interdisciplinary field of study. Besides, it opens up a new perspective for the interdisciplinary approach in combination with cooperative ESP teaching and learning.

The project discussed in this paper manifested the following interdisciplinary characteristics. It was integral, vertical, holistic, open, and highly stimulating. The IBP incorporated two educational levels - secondary and tertiary - into a unique integrity of a holistic vision of knowledge and understanding of an ESP problem. To prove Dr. Frank Delli Carpini's ideas (Carpini, 2017), we can draw a number of didactic conclusions:

- Bilingual interdisciplinary collaboration is a planned interdisciplinary activity which is performed over a fixed period of time, intended to achieve a particular professional purpose in an artificially created bilingual educational environment.

- Bilingual interdisciplinary collaboration between subject teachers and ESP teachers facilitates both foreign language and subject matter knowledge acquisition in ESP students. Having to develop foreign language skills and master the subject matter (subject/discipline content) simultaneously within the educational environment of the IBP, the ESP students perform a two-fold task which makes learning (training) more challenging but exciting.

- The IBP constructs new meanings and prompts inquiry-based language and cultural learning that bridges educational and social differences among the learners and improves their academic achievement, professional skills and language performance.

- Bilingual interdisciplinary collaboration between subject and ESP teachers enhances a more meaningful understanding of the students' career needs.

- Bilingual interdisciplinary collaboration compels subject and ESP teachers to re-evaluate their teaching experiences and update teaching styles and methods. 
- Bilingual interdisciplinary collaboration is effective for adult learners and is likely to result in a significant increase in enrolment figures at vocational schools in this country.

The IBP is a constructive innovative strategy that bridges disciplines, stimulates the learners to move through interdisciplinary lines, translates study into practice, effectively applies interdisciplinary knowledge and know-how acquired in professional environments. We find it appropriate to conclude the paper with W. E. B. Du Bois' adage: "A system of education is not one thing, nor does it have a single definite object, nor is it a mere matter of schools. Education is that whole system of human training within and without the school house walls, which molds and develops men".

\section{Works Cited}

Carpini, D., "Teacher Collaboration for ESL/EFL Academic Success", Web http://iteslj.org/Techniques/DelliCarpini-TeacherCollaboration.html, New York, Lehman College (accessed 17 May 2017).

Choi, B.C.K. and Pak, A.W., "Multidisciplinarity, interdisciplinarity and transdisciplinarity in health research, services, education and policy: 1 . Definitions, objectives, and evidence of effectiveness" in Clin Invest Med, 29 (6)/2006.

Hughes, P., "Interdisciplinarity in general education: an Australian case study" in International Symposium on Interdisciplinarity in General Education, Paris, Unesco house, 1985.

Jacobs, J.A. and Frickel, S., "Interdisciplinarity: a critical assessment", in Annual Review of Sociology, 2009. https://proseminarcrossnationalstudies.files.wordpress.com/2009/11/interdiscipl inarity_ars_(accessed 16 May 2017).

Jensenius, A. R., "Disciplinarities: intra, cross, multi, inter, trans", www.arj.no/.2012/03/12/disciplinarities-2 (accessed 23 May 2017).

Martynyuk, V. A., "Transdisciplinary properties of innovative multilingual educational environment at vocational schools" in Proceedings of Kropyvnytski national university named after V. Vynnychenko. Problems of methodology in technological sciences, 11/ 3, 2017.

Meeth, L. R., "Interdisciplinary studies: A matter of definition" [Electronic resource] in Change: The Magazine of Higher Learning, Vol. 10, Iss. 7, 1978,Web version available from: Taylor \& Francis Online. doi: 10.1080 /00091383.1978.10569474 (accessed 16 May 2017).

Nicolescu, B., Transdisciplinaritatea. Manifest, translated into Romanian by Horia Mihail Vasilescu, Iaşi, Polirom Publishing, 1999, second Romanian edition: Junimea Publishing, Iaşi, 2007.

Olyinyk, V., "Interdisciplinarity in unceasing professional development of teachers in the system of in-service pedagogical education in Ukraine" in Interdyscyplinarność pedagogiki i jej subdyscypliny / pod red. Zofu Szaroty 
Franciszka Szloska, Radom, Wydawnictwo Naukowe Instytutu Technologi Eksploatacji, 2013.

Seipel, M., "Interdisciplinary: An Introduction", Kirksville, Truman State University, Web http://www2.truman.edu/ mseipel/Interdisciplinarity.pdf (accessed on May 23, 2017).

Zabolotna, O. A., "Transdisciplinarity as a strategy of practical realization of alternative education" in Proceedings of Nizhyn State University named after Mykola Hohol. Vol. 6, 2012.

\section{BIONOTES}

Veronia MartynyuK is PhD (Pedagogy), Associate Professor of Chernivtsi high school of commerce affiliated with Kyiv National University of Trade and Economics, Ukraine. Her research interests are EFL methodology; interdisciplinary multilingual communication. She has published extensively in various journals as well as collections of essays. Among her latest articles are "Transdisciplinary Characteristics of Innovative Multilingual VET Environment" in Problems of Methodology in Technological Sciences No 3/2017, Kropyvnytskyi, Ukraine; and "Strategic Partnership in Fostering International VET Cooperation" in Relevant Issues of Science in Central and Eastern European Countries, 2019, Riga, Latvia. She is the author of twelve books on English for Specific (Professional) Purposes.

Email: veronicamartynyuk@gmail.com

Olena Kravchenko is Assistant Professor of Chernivtsi Yuriy Fedkovych National University, Department of English, Chernivtsi, Ukraine. Her research interests are group projects in language learning, interdisciplinary aspect of TEFL/ ESP, imaginative discourse analysis. She has published extensively in various journals as well as collections of essays. She is the author of six books on English for professional communication.

Email: okravchenko33@yahoo.com 
